\title{
Entre "o Romantismo tão gasto e o Realismo tão vasto": os tableaux de Joaquim Serra e o ecletismo
}

\section{Vagner Camilo}

\begin{abstract}
Resumo: Este ensaio detem-se numa parcela da poesia de um nome hoje praticamente ignorado na tradição literária brasileira: Joaquim Serra (1838-88). Dono de extensa produção, o maranhense foi importante jornalista, político, grande publicista ligado à imprensa abolicionista, dramaturgo e poeta. Como poeta, embora tenha também composto versos em diálogo com as tendências dominantes na lírica romântica, Serra teve seu nome associado a um gênero de poesia ruralista ou sertanista, que surgiu no quadro dessa mesma geração romântica. Mas aqui, o que interessa da produção poética de Serra não são os quadros rústicos e sim os tableaux urbanos marcados pelo registro humorístico na caracterização de cenas e tipos, e concebidos em intenso diálogo com o teatro, numa mescla ou fusão de gêneros que, graças ao salvo-conduto do romantismo, explorou em outros tantos momentos de sua obra. Palavras-chave: Joaquim Serra, humor romântico, mistura de gêneros.
\end{abstract}

\footnotetext{
Abstract: This paper proposes a brief commentary about a part of the poetry of a name now virtually ignored in the Brazilian literary tradition: Joaquim Serra (1838-88). Creator of a extensive body of work which is widely forgotten, the author born in the state of Maranhão was also an important journalist, politician, a great political writer linked to the abolitionist press, playwright and poet. As a poet, although having also created verses in dialog with the predominant tendencies in romantic literature, Serra became associated with a ruralist or "sertanista" genre of poetry, which surfaced inside this same romantic generation. Herein, what strikes most about Serra's poetry work aren't the rustic pictures but the urban tableaux with a humorous registry of the characterization of scenes and types, and conceived in a intense dialog with the theatre, in a mixture or fusion of genres which, thanks to the safe conduct of the Romanticism, he explored in several other moments in his works. Keywords: Joaquim Serra, romantic mood, fusion of genres.
} 
Dono de extensa produção em prosa e verso, hoje praticamente ignorada, o maranhense Joaquim Maria Serra Sobrinho (1838-88) foi importante jornalista e político, seguindo, ao que parece, as pegadas do pai, Leonel Joaquim Serra, que também militara na política e no jornalismo maranhense, redigindo periódicos como O Cometa (1835) e a Crônica dos Cronistas (1838). Formado em humanidades, o filho foi ainda professor de gramática e literatura no Liceu Maranhense, escritor, teatrólogo e poeta. Isso sem esquecer sua incursão pela política, como secretário de governo da Paraíba (1864-7) e deputado geral por sua província natal (1878-81).

Passando brevemente para suas funções de maior projeção, sua atividade como jornalista se iniciou muito cedo, com a publicação dos primeiros escritos (1858-60) no Publicador Maranhense, folha oficial, política, literária e comercial fundada em 1842 por João Francisco Lisboa e redigida, desde 1856, por Sotero dos Reis. ${ }^{1}$ Em 1862, Serra fundou com alguns amigos o jornal $A$ Coalição (sic), em substituição ao hebdomadário Ordem e Progresso (criado em janeiro do ano anterior), ambos órgãos do partido progressista (produto da liga entre liberais e conservadores). Cessada a publicação de A Coalição quatro anos depois, Serra fundou, em 1867, o Semanário Maranhense, revista literária que, no ano seguinte, parou de circular. Em 1883, legou um livro que inventariava o jornalismo de sua Atenas brasileira, sabidamente terra de grandes publicistas como o autor do Jornal de Timon. O livro Sessenta anos de jornalismo - a imprensa do Maranhão, 1820-80 teve repercussão imediata, suscitando uma segunda edição naquele mesmo ano. Com a mudança em 1868 para a Corte - onde já estivera, entre 1854 e 1858, com o intuito de ingressar na Escola Militar, carreira logo abandonada -, Serra se projetou como o cronista empenhado de "Argueiros e Cavaleiros" e “Tópicos do Dia", de O País, e dos "Folhetins Hebdomadários" da Gazeta de Notícias. $\mathrm{Na}$ verdade, ele já fora apresentado literariamente à Corte antes, por Machado de Assis, numa das crônicas do Diário do Rio de Janeiro (de 24 de outubro de 1864). Mas só quando fixou residência definitiva na Corte Serra fez carreira admirável no mundo do jornalismo, chegando a ocupar o cargo de diretor do Diário Oficial

Para a composição deste pequeno retrato intelectual, valho-me das seguintes fontes: BLAKE, Sacramento. Dicionário bibliográfico brasileiro. Conselho Federal de Cultura, 1870, v. 4 (fonte obrigatória dos demais); a biografia constante do site da Academia Brasileira de Letras; o discurso de posse de Olegário Mariano (que ocupou a mesma cadeira de José do Patrocínio, quem, aliás, elegeu Serra por patrono), além de informações colhidas em Machado de Assis e Joaquim Nabuco, referidos adiante. No que tange especificamente à sua trajetória como jornalista, valho-me do que o próprio Joaquim Serra registra, sob o pseudônimo de Ignotus, em seu Sessenta annos de jornalismo: a imprensa no Maranhão (1820-1880). 2. ed. Rio de Janeiro: Faro \& Lino Editores, 1883.

Teresa revista de Literatura Brasileira [12|13]; São Paulo, p. 384-420, 2013 • 385 
(1878-82), do qual, com dignidade, se exonerou por divergir do gabinete liberal de janeiro de 1882 .

Sua trajetória como publicista foi marcada pela intensa campanha abolicionista e pela tenacidade com que combateu o escravagismo autoritário que se escorava em argumentos de uma absurda lógica econômico-política, incessantemente rebatidos por Serra, para quem nenhum Império poderia, com honestidade, assentar suas bases sobre tamanha ignomínia. Em passagem de Sessenta anos de jornalismo, depois de destacar o fato de haver sido a imprensa maranhense uma das mais ardentes e antecipadas na propaganda abolicionista, tendo à frente João Francisco Lisboa, Serra criticava as concessões revoltantes feitas à escravidão por falsos filantropos que, ao compararem a condição do escravo brasileiro com a do faminto operário europeu, conseguiam cinicamente ver mais vantagens na daquele que na deste, defendendo, assim, a manutenção do status quo. ${ }^{2}$

Serra que, segundo André Rebouças, foi o publicista que mais escreveu contra os escravocratas, fundou e dirigiu ainda os periódicos A Reforma e A Folha Nova. Sobre sua contribuição, anos a fio, para o primeiro periódico - no qual colaboraram nomes de destaque da política nacional e da administração pública, como Francisco Octaviano, Tavares Bastos, Afonso Celso, Rodrigo Otávio e José Cesário de Faria Alvim -, afirmou Joaquim Nabuco que Serra foi a vida do jornalismo liberal e o criador da moderna imprensa política, pela dedicação heroica e pelo sacrifício à causa abolicionista. Serra assumiu, ainda, o periódico O Abolicionista, órgão da Sociedade Brasileira Contra a Escravidão, do qual foram estampados apenas quatro números entre 1880 e 1881 . De formato pequeno, não declarava quem compunha seu corpo editorial (para evitar expor seus integrantes) e não trazia anúncios, uma vez que nem comerciantes, nem industriais desejavam associar seus nomes a esse tipo de publicação.

O mesmo ano que assistiu à Abolição em 13 de maio testemunhou, poucos meses depois, a morte do grande publicista, como trataria de assinalar, alguns dias após seu sepultamento, Machado de Assis: "feita a abolição, desabrochada a flor, morria ele"... Vale a reprodução de parte do retrato traçado pelo autor de Esaú e Jacó, no qual, além da atuação como publicista abolicionista, destaca ainda certa particularidade da produção poética do maranhense que muito interessa aqui: o humor. 
Era modesto até à reclusão absoluta. Suas ideias saíam todas endossadas por pseudônimos. Eram como moedas de ouro, sem efígie, com o próprio e único valor do metal. Daí o fenômeno observado ainda este ano. Quando chegou o dia da vitória abolicionista, todos os seus valentes companheiros de batalha citaram gloriosamente o nome de Joaquim Serra entre os discípulos da primeira hora, entre os mais estrênuos, fortes e devotados; mas a multidão não o repetiu [,] não o conhecia. Ela, que nunca desaprendeu de aclamar e agradecer os benefícios, não sabia nada do homem que, no momento em que a nação inteira celebrava o grande ato, recolhia-se satisfeito ao seio da família. Tendo ajudado a soletrar a liberdade, Joaquim Serra ia continuar a ler o amor aos que lhe ensinavam todos os dias a consolação.

Mas eu vou além. Creio que Joaquim Serra era principalmente um artista. Amava a justiça e a liberdade, pela razão de amar também a arquitrave e a coluna, por uma necessidade de estética social. Onde outros podiam ver artigos de programa, intuitos partidários, revolução econômica, Joaquim Serra via uma retificação e um complemento; e, porque era bom e punha em tudo a sua alma inteira, pugnou pela correção da ordem pública, cheio daquela tenacidade silenciosa, se assim se pode dizer, de um escritor de todos os dias, intrépido e generoso, sem pavor e sem reproche.

Não importa, pois, que os destinos políticos de Joaquim Serra hajam desmentido dos seus méritos pessoais. A história destes últimos anos lhe dará um couto luminoso. Outrossim, recolherá mais de uma amostra daquele estilo tão dele, feito de simplicidade e sagacidade, correntio, franco, fácil, jovial, sem afetação nem reticências. Não era o humour de Swift, que não sorri, sequer. Ao contrário, o nosso querido morto ria largamente, ria como Voltaire, com a mesma graça transparente e fina, e sem o fel de umas frases nem a vingança cruel de outras, que compõem a ironia do velho filósofo. ${ }^{3}$

O excerto é interessante por mais de um motivo, entre os quais o de iluminar não só a forma de comicidade característica dos escritos de Serra, mas, por contraste, do próprio sense of humour machadiano. Para o escopo deste ensaio, interessa só o humorismo do primeiro, do qual tratarei mais adiante. Sigo, ainda, traçando o perfil intelectual e literário do poeta maranhense. 
Acercando-se do domínio do literário, Serra enveredou pela dramaturgia, estimulado pela inauguração da Ópera Nacional do Rio de Janeiro, que, segundo ele, causou verdadeira "hidrofobia patriótica", dado o "açodamento com que nos atiramos desapiedados sobre o papel, a fazer libretos para as partituras nacionais". ${ }^{4}$ Julgando que "o gênero espanhol das zurzuellas" fosse "o mais próprio para o nosso teatro", ${ }^{5}$ compôs a ópera-cômica Quem tem boca vai a Roma, que não chegou, todavia, ao palco porque censurada pelo Conservatório Dramático, com a alegação de inconveniência devido à imagem depreciativa da Igreja e de seus representantes. Serra publicou os pareceres dos censores (datados de 1857) na edição impressa da peça, logo depois do prefácio endereçado ao dr. Raimundo A. de Carvalho Filgueiras, em que argumenta contra a pecha de imoral, estabelecendo comparações significativas com outras tantas representações cômicas da figura do religioso, sobretudo na tradição local:

Mas, se por um lado as expressões animadoras do Conservatório satisfizeram o meu orgulho de autor (nobre ambição, como és apreciável nos anões!) [,] pelo outro lado doía-me a injustiça do Conservatório, que, licenciando a Tia Bazu, Bodas de Merluchet e outras produções decotadas demais achava vislumbres de desonestidade nos meus humildes lapsos de lápis.

Quero que por conveniências, que respeito, não se apresentasse em cena um grosso Franciscano, desses pintados pelo Bocage e Álvares de Azevedo, concordo em parte; mas a essa inconveniência unir-se a pecha de imoral, é que eu não podia tragar.

O Frei Gil do Antônio José, o Noviço da comédia do Pena e o próprio Tartufo de Molière aí estavam para me autorizar a exibição pública de um fradalhão de bom quilate; mas admitindo que a sátira nesses casos possa pecar por muito genérica e ter seus laivos de impiedade, eu concordaria em tudo com o Conservatório menos com a pouca decência de meu trabalho, pautado pelo mote de José de Alencar- fazer rir sem fazer corar. ${ }^{6}$ 1863, p. 4. A maioria das obras de Joaquim Serra encontra-se hoje disponível no site da Biblioteca Digital Brasiliana USP, <www.brasiliana.usp.br>.

5 Idem, p. 4.

6 Idem, p. 4-5. 
Ainda que em chave negativa, o primeiro censor confere um sentido simbólico ou mais alegórico às personagens e ao enredo da ópera-cômica, cuja ação transcorre no interior do Rio de Janeiro e trata da história dos jovens apaixonados Arabela, filha de pobres lavradores já mortos, e o pintor Eduardo. Embora prometidos, acabam sendo impedidos de casar pela tia da moça. Responsável pela órfã, d. Catarina nega a mão da sobrinha, aconselhada por frei Benedito, que acusava Eduardo de ser seguidor da doutrina de Voltaire. A verdadeira razão é que o velho frei franciscano desejava seduzir e desonrar Arabela. Quem desconfia das reais intenções de frei Benedito, buscando investigá-las e arquitetar uma estratégia para desmascará-lo, é Francisco (vale atentar a este nome, estabelecendo a simetria entre protagonista e o antagonista encarnado pelo frei franciscano), estudante de matemáticas, que vem da cidade justamente para visitar Arabela, sua irmã de leite. O traço cômico de Francisco (que lhe confere "particular sainete", como diz um dos censores) é recorrer o tempo todo a explicações com base numa lógica matemática e em teorias geométricas. Assim, ele, por força do ofício que busca abraçar na Escola Militar (lembre-se que o próprio Serra pensou, um dia, em ingressar nessa carreira, o que ajuda a pensar o papel de raisonneur do personagem na peça), calcula o melhor meio para arrancar a confissão das reais, libertinas e aviltantes intenções de frei Benedito, garantindo, com isso, ao par central, o happy end de toda comédia.? O desmascaramento representa, desse modo, uma vitória da ciência e da razão sobre a religião. O primeiro censor diz ser fácil extrair a moralidade da peça que, bem ao gosto dos luminares da época, despreza o conhecimento cristão, sobrepujado pelo conhecimento racional, matemático que, segundo ele, se ajusta fácil ao interesse econômico e ao utilitarismo moderno, revertendo, de maneira regressiva, os argumentos da moderna crítica do capital à causa da religião, além de negar ao teatro a autoridade ou o direito de fustigar os religiosos que profanam a lei de Cristo. É o que se vê no trecho a seguir do parecer que, pelo grau de intolerância, chega quase a reivindicar para a mesa censória um papel que fora exercido outrora pelos tribunais da Inquisição:

[...] orgulhosos pelas descobertas com que (ímpios) julgam ter enfraquecido o poder de

Deus, empregam-se quase exclusivamente nas questões da elasticidade dos algarismos, 
dóceis ao jugo das finanças e da economia política, ciências cujos foros colocam acima dos que tem adquirido a teologia, que não dá regras para amontoar moedas. Sabe que sem ser isto, só alguma excentricidade, algum escândalo estrondoso os pode distrair de seus estudos capitalísticos, industriais e utilitários feitos por amor proximal. Debaixo destas vistas, o autor atira com um grande escândalo em cena, certo de conseguir o favor do público, que há de conseguir, repito, se a peça for representada.

Tanto o autor reconhece que seu provérbio Quem tem boca vai a Roma encerra imoralidade contra a religião, que não o finda sem contar uma pequena palinódia... mas a sorte estava lançada, ele passou o Rubicon. [...] O sacerdócio é muitas vezes exercido por mãos indignas e caracteres depravados, mas não há de ser o teatro, por mais que fustigue esses profanadores da lei do Cristo, que os há de chamar à razão no império da Cruz. São relapsos eivados da gangrena do século, contaminados da podridão dos vícios, para os quais nem as masmorras do santo ofício trariam correção. ${ }^{8}$

É importante observar, de passagem, que não só o matemático é poupado, mas também o pintor, o que equivale a conferir à arte mérito equiparável ao da ciência e da razão.

Por último, vale notar que o contraponto campo $x$ cidade, província $x$ corte está presente em vários momentos da obra de Serra. Eduardo, por exemplo, é tido pelo coro dos moradores da província como bom rapaz justamente por ser "o excelente pintor que não quer saber da vida na cidade..." ${ }^{9}$ Veremos adiante a reiteração dessa visão na poesia do maranhense.

O veio cômico-satírico de Joaquim Serra se estende a outros gêneros fora do teatro, como se pode notar no poema "A capangada", cujo subtítulo diz se tratar de paródia muito séria, tendo sido publicado, com o nome de "Amigo Ausente", em 1872, pela tipografia da Reforma, responsável pelo periódico liberal para o qual Serra colaborava. O alvo da sátira são as estratégias eleitorais e a composição ministerial, atacando nada mais, nada menos do que o Visconde do Rio Branco, considerado um dos maiores estadistas do Segundo Reinado por uma figura do peso de Joaquim Nabuco, que louva a atuação política de José Maria da Silva Paranhos na implantação de medidas liberais, a despeito de sua filiação ao partido conservador. Boris Fausto nota, a esse respeito, que, ao propor a Lei do Ventre Livre, o gabinete conservador de 
1871, presidido por Rio Branco, arrebatou "a bandeira do abolicionismo das mãos dos liberais". ${ }^{10}$ A investida satírica de Serra contra o visconde e seu gabinete pode talvez ser lida, nesse sentido, como fruto do ressentimento de um liberal tremendamente empenhado na causa abolicionista que vê sua militância solapada pelo inimigo político-ideológico, mas o fato é que parece haver muito fundamento histórico nesse ângulo nada enobrecedor por onde o poeta maranhense flagra a atuação "pública" do venerando Rio Branco, a quem se refere, num retrato picaresco, como o

... grande Paranhos Malasarte

Hoje feito valido e potesdade!

O Poder Pessoal com jeito e arte

Patriarca te fez dessa irmandade! ${ }^{11}$

Talvez mais do que o gabinete conservador de 7 de março de 1871, presidido por Paranhos, ao mesmo tempo que assumia a presidência do Conselho de Ministros, o poema parece aludir à sequência de gabinetes conservadores que antecederam esse do visconde, como o do Marquês de São Vicente, de setembro de 1870, referido expressamente nos versos. Todos participariam da capangada referida no título, liderada por Rio Branco, contra a qual Serra busca empregar, em reação à violência armada de que ela se valeu para manipular urnas e eleições, "a arma perigosa" da "chalaça", a fim de que "a galhofa sepulte um ministério". ${ }^{12}$

O subtítulo (que exemplifica mais uma vez a mescla de registros com que o poeta frequentemente opera) se explica pelo fato de o poema se construir à custa da "paródia muito séria" de Os lusíadas, apropriado desde a dedicatória, como comprovam as estrofes abaixo, vertidas, é claro, em oitava rima e versos decassilábicos:

A malta de ministros desbragados,

Essa caterva ilustre e veneranda,

Mais os seus gazeteiros alugados,

10 FAUSTO, Boris. História do Brasil. São Paulo: Edusp, 1999, p. 217. Sobre a atuação de Rio Branco na reforma de 1871 e em meio às consequências político-partidárias dessa lei, ver CARVALHO, José Murilo. A construção da ordem: a elite política imperial; Teatro de sombras: a política imperial. Rio de Janeiro: Editora da UFRJ; Relume-Dumará, 1996, p. 286 ss.

11 [SERRA, Joaquim.] A capangada. Paródia muito séria pelo Amigo Ausente. Rio de Janeiro: Typ. da "Reforma", 1872, p. 4.

12 Idem, p. 3-4, 9 e 11 
Escritores da praia e de quitanda;

A enorme quadrilha de embrechados

E que cheira a polícia que tresanda,

Gente parva e ruim, súcia de bobos,

Faminta do orçamento como lobos,

E também as imensas brilhaturas

Dos Godoys e dos Bentos presidentes

Os filhotes, as santas criaturas,

Afins do ministério e seus parentes,

Tais verdades cruíssimas e duras,

Nestes versos tornadas bem patentes,

Cantando espalharei por toda parte

Se a tanto me ajudar pachorra e arte.

Cessem do Mal-das-Vinhas as bisnagas

E do Padre-Kelé a glória fina,

Calem de Pai-Quibombo as artes magas

E do Urso a voraz fome canina,

Qu'eu canto do Brasil as sete pragas,

O gabinete herói da alicantina,

Cesse tudo o que a musa-chula canta,

Pois assunto mais chulo se alevanta.

E vós, calças azuis da fidalgagem,

Sede à musa propícia e eloquente,

$O$ pendão que me guie na viagem,

Que pretendo fazer alegremente;

Leve o cântico meu fagueira aragem,

Venha estilo humorístico e corrente,

E a galhofa sepulte um ministério

Que jamais pode ser tomado a sério. ${ }^{13}$

13 Idem, p. 3. 
A paródia segue na contrafação de célebres episódios camonianos, como o de Inês de Castro:

Estavas, ó Chuleta, em teu sossego

Lá no Morro do Chá, mansão querida,

Naquele engano d'alma ledo e cego,

Passando milagrosa e fresca vida;

Não tinhas outra ideia e outro emprego

Senão amar Manduca, doce lida!

Aos montes ensinando e às ervinhas

O nome que no peito escrito tinhas!

Do ausente amador te referiam

Cousas tristes que muito te aterravam:

Ele na corte estava, onde diziam

Que do Alcazar as ninfas o enlevavam.

À noite feios sonhos te oprimiam.

Do dia mil terrores te assaltavam;

Não podendo conter o desvario

Te pusestes em caminho para o Rio. ${ }^{14}$

Ou ainda se apropria do Canto v, desde a abertura, quando já cinco sóis eram passados, até a aparição do gigante Adamastor, a quem é equiparada, na chave do grotesco, a figura ridicularizada de Aristeu de Itaverava, que tratará de violar as urnas eleitorais a serviço dos interesses da capangada:

Porém já cinco sóis eram passados

Depois desse congresso eleitoral,

E os ministros ainda atarantados

Andavam com o negócio capital!

Tinham mesários seus bem despejados

Nas paróquias e a gente marcial,

Mas o povo era todo adversário,

E o Duque-Estrada um grande salafrário.

[...]

14 Idem, p. 5-6.

Teresa revista de Literatura Brasileira [12|13]; São Paulo, p. 384-420, 2013 • 393 
Correram o reposteiro, e uma figura

Em frente apareceu robusta e válida,

De sertaneja, insigne estatura,

O rosto aparvalhado, a barba esquálida,

Olhos encarniçados e a postura,

Ridícula e má a cor vermelha e cálida,

Medonha a penca, furibunda tromba,

Nariz que tudo fere e tudo arromba!

E disse: Ó gente ousada outrora e brava,

Como assim conspirais nesta cafurna,

Sem que o Aristeu de Itaverava

Seja presente à reunião noturna?

O que vos falta? eu sou pesada clava

Capaz de pôr em cacos férrea urna!

Ninguém ao meu nariz aqui resiste,

Falai, falai, que estou de lança em riste! $!^{15}$

Mais adiante, Serra faz de Paquetá a versão degradada da Ilha dos Amores, a que tem acesso, como prêmio, a malta de ministros do conselho que vence à força as eleições. Num lauto piquenique com iguarias locais e a companhia de ninfas modernas, do Alcazar e do Paraguai (aludindo, decerto, ao fato de Paranhos ter sido designado como secretário do ministro plenipotenciário na região do rio da Prata, o futuro Marquês de Paraná). Veja o excerto, que começa com a evocação da musa da épica:

Agora tu, Calíope, me ensina

O modo de contar a patuscada:

Que fizeram os heróis da trampolina

Depois qu’a apuração foi publicada;

Empresta-me harmonia peregrina,

Leva-me a Paquetá, ilha encantada,

Ali a festa foi, jardim de Armida,

Ou nova Ilha de Amores tão querida.

15 Idem, p. 8-9. 
Foram do bródio os grandes cabalistas,

Os cabos mais audazes da eleição,

Os delegados que embolaram listas,

Benevides, Laguna e o Sayão;

Todo o estado maior dos governistas,

O ministério em peso de fardão,

E para o piquenique amenizar

Ninfas do Paraguai e do Alcazar. ${ }^{16}$

A própria crise encenada pelo cantor épico de Os lusíadas, que, no Canto viI, sentindo faltar-lhe a inspiração, abre espaço para o lamento indignado pelo modo como a pátria tem tratado a quem só pretende cantar a glória lusitana, é retomada aqui pelo parodista no canto final (também de número viI) de A capangada:

Não mais, Musa, não mais que a contragosto

Vou ficando co'a alma exasperada,

Acabo quase irado e com desgosto

Aquilo qu'encetei por caçoada!

Sim, que sobe-me o sangue à mente, ao rosto

Vendo a gente perdida e desgraçada,

Que governando está a nossa terra

Vivendo co'a moral em dura guerra!

Consola-me, porém, grata lembrança, Que breve isto há de ter um paradeiro,

Pois nem sempre estará na governança.

Um partido detrás do reposteiro.

Quando a hora soar de atra mudança.

Soltará o seu grito derradeiro

Dos selvagens a negra fatal horda,

Que colocou-nos de um abismo à borda.

Então não mais Paranhos, nem Alfredo,

E Ribeiro da Luz, Manoel Corrêa,

16 Idem, p. 13-4. 
E Junqueira, Duarte de Azevedo;

Barros Barreto, caravana feia!

A rabadilha enorme que faz medo

E que o orçamento hoje rodeia

Há de podre cair, volver ao nada...

E dou minha missão por terminada. ${ }^{17}$

Algo dessa crítica ao estado de corrupção generalizada na vida política, social, econômica da nação, comparece também em Fábio, poema de Serra cuja autoria fictícia é atribuída a certo frei Bibiano, embora publicado por aquele que se nomeia apenas como Um Amigo, responsável pelas longas notas ao final do volume, que dão o fundamento histórico às alusões contidas na narrativa em versos.

O protagonista que dá nome ao poema é um jovem cioso dos brios da pátria, da soberania do Estado abalada pela aplicação do Abeerden Act e os inúmeros acidentes diplomáticos que o cercaram, bem como os que envolveram a Questão Christie, entre outros episódios. Ele se mostra indignado diante dos horrores da escravidão, denunciada num tom veemente em que bem se reconhece a oratória condoreira e, em certas passagens, a evidente apropriação de trechos de "O navio negreiro" e outros poemas castroalvinos. Decide participar da guerra do Paraguai, sobre a qual se detém boa parte do poema, por esse seu empenho nas causas nacionais.

O retrato de Fábio é o de uma espécie de anti-Macário, como se nota nos versos abaixo, que claramente se apropriam, pela negativa, dos perfis byronianos cunhados por Álvares de Azevedo com um misto de frescor juvenil e fatigada senilidade (diria Antonio Candido), numa evidente atitude crítica, pessimista e sarcástica em relação ao otimismo e o empenho nacionalista da intelectualidade áulica ligada ao IHGB e à primeira geração romântica: $:^{18}$

17 Idem, p. 20.

18 Busquei examinar essa descrença e tal sarcasmo em Macário e no perfil do eu poético de Álvares de Azevedo, a partir da apropriação da tópica clássica do puer senex, tendo em vista a atitude crítica do poeta em relação ao nacionalismo e ao contexto histórico-político do Segundo Reinado. Ver: CAMILO, Vagner. Álvares de Azevedo, o Fausto e o mito romântico do adolescente no contexto político-estudantil do Segundo Reinado. Itinerários n. 33. Araraquara: UNESP, 2011, p. 61-108. Ver também CUNHA, Cilaine Alves. Entusiasmo indianista e ironia byroniana. São Paulo: USP, 2000 (tese de doutorado). 
Era Fábio seu nome. A juventude

Não a vazara nas febris orgias

Das taças ao clarão, à fúria rude

Das impudicas, torpes alegrias;

Neste vasto cenário onde a virtude

Caiu de rasto ao som das vozerias,

Onde a velhice e a mocidade agora

D’alma o pudor frenética desflora

[...]

Era bem moço, e devassando ousado

Da ciência os umbrais, armas vestira

Com que da vida à luta preparado

O bom defenda, o miserável fira.

Sacerdote do bem, fora sagrado

Em lições que o saber e a honra inspira.

Partiu seguro e lá no torvelinho

Da vida humana foi abrir caminho. ${ }^{19}$

O estado de corrupção reinante na vida pública, somado à alienação generalizada da jovem geração que lhe é contemporânea, alcança o domínio das artes, quando o eu poético, a dada altura de Fábio, se dirige à musa lamentando a carência de grandes poetas e o baixo nível da vida literária nacional depois da morte, respectivamente, de Gonçalves Dias, Junqueira Freyre, Álvares de Azevedo e Araújo Porto-Alegre:

Aqui, ó Deusa, à copa dos coqueiros

Raros cultores cercam teus altares;

O poeta dos índios forasteiros

Dorme sem vida nos profundos mares;

O moço monge à sombra dos mosteiros

Já não fere o laúde dos pesares;

E o gênio a quem devora amargo afã

Pende também da vida na manhã. 
Aqui por ímpias mãos pelos bordéis

Arremessam-te nua e sem pudor,

Os sacerdotes teus, teus menestréis

Buscaram na lascívia o teu amor,

E a virgem candidez dos teus lauréis

Nas orgias rasgaram com furor,

De teu aspecto a mágica beleza

Transfiguram na imagem da torpeza.

Salve o cantor do gênio aventuroso

Que do oceano os términos quebranta,

E dentre a escuridão do abismo undoso

Ignaras terras, povos alevanta.

Salve do vate o metro sonoroso,

A voz altiloquente com que canta.

Se o Nauta à Ibéria um mundo novo entrega

Outro o poeta à pátria absorta lega. ${ }^{20}$

A denúncia do baixo nível da produção literária e da prostituição da musa aqui presentes já aparecia nos poemas dedicados ao Alcazar lírico, conforme veremos adiante. A justificativa para esse estado de coisas, visto como consequência da cópia exótica do realismo francês no Brasil, também já comparecia em outro poema, "Ecletismo", e retorna aqui em uma das notas que acompanham os versos acima, quando Serra estabelece uma aproximação entre essa situação das artes no país com o que o dramaturgo, escritor e jornalista Charles Monselet falava sobre a irrelevância e a venalidade das artes na França durante a monarquia constitucional, relacionando, assim, a crise da criação artística ao regime político condenado:

Os poetas moderníssimos ainda não deram de si cousa que se não empoeirasse nas bibliotecas. Alguns moços de talento há, porém mais folhetinistas do que poetas dramáticos ou romancistas. A literatura é uma cópia exótica do realismo francês. Podem-se-lhe aplicar estas palavras de Charles Monselet com referência à literatura em França: - Pendant ces ans de monarchie constitutionelle, la littérature a été tellement compromise par une nuée détourdies; on en a tellement fait une chose de bavadage et négoce...

20 Idem, p. 19 
Tirando os jurisconsultos e alguns historiadores, dos autores vivos não se ergueram à posteridade. $^{21}$

Serra opera, frequentemente, com um híbrido de gêneros, o que não deixava de ser justificável pelos preceitos estéticos do romantismo então em voga, mas que também revela uma inquietação com as limitações impostas pelas convenções genéricas. Compôs, assim, o romance em versos Um coração de mulher, no qual, para além do enredo melodramático e moralizador, já desponta o gosto pela composição dos cenários campesinos em que se notabilizaria, devido à modalidade poética mais praticada por ele, da qual trato a seguir. Antes, porém, gostaria de registrar rapidamente, que a mescla ou fusão de gêneros foi também promovida em suas crônicas abolicionistas, algumas das quais redigidas em versos, como dá exemplo Raimundo Magalhães Jr. ao recolher uma delas em sua Antologia do humorismo e da sátira.

\section{Serra poeta lírico e poeta sertanejo}

Como poeta, Serra compôs alguns poucos poemas inspirados em certas tendências da lírica romântica de então, em especial a de Álvares de Azevedo. São, em geral, versões medianas dentre as quais valesse talvez destacar três momentos de exceção, em que sua poesia no gênero me parece alçar ao nível do autor da Lira dos vinte anos. É o caso de "Sonhando", incluído em Quadros:

\section{Sonhando}

A noite ia bela tocando a seu termo,

A brisa passava qual eco de amor,

E já descorada, sentindo a alvorada,

A lua mostrava mais pálida cor.

O mar preguiçoso n’areia batia

De leve, qual som de trêmulo beijo

De amante ditoso, que vai receoso

Beber as primícias de um longo desejo. 
$\mathrm{O}$ ar era brando, corriam perfumes

Das flores abertas por entre a verdura,

$O$ rórido prado e o céu anilado

Mostravam nessa hora igual formosura.

E tu descansavas do sono nos braços,

Sonhando venturas, comigo sonhando!

Sentias meu peito, em chamas desfeito,

Talvez junto ao teu bater desmaiando.

Um riso amoroso abria teus lábios,

A face de um anjo se via em tua face;

Sem arte vestida, deitada, dormida,

No teu desalinho, ai... quanto realce!

E vi-te dormindo e quis despertar-te,

Chamei por teu nome, um grito soltei!

Mas, ah! quem dormia era eu que te via,

Era eu que sonhava, e que despertei! ${ }^{12}$

Além do poema homônimo, os versos acima dialogam com outros tantos momentos da Lira ("Quando à noite no leito perfumado" ou "Pálida à luz da lâmpada sombria", por exemplo) ao repor a situação paradigmática ideal do eu lírico contemplando o sono da amada, indagando por quem sonha e por que sorri a bela adormecida, que, numa nota de sensualismo, comparece com as roupas em desalinho no leito, realçando suas formas juvenis, enquanto o apaixonado se consome em chamas e sente seu peito bater junto ao dela, quase a desmaiar. Como é recorrente também nos poemas de Álvares de Azevedo, o desejo e o erotismo são projetados na composição do cenário natural, evocado nas três primeiras estrofes. A diferença é que Serra rompe a ambiguidade tantas vezes mantida nos poemas azevedianos, quando, no final dos versos, ao gritar pela bela adormecida, com o intuito de acordá-la, percebe, despertando, que quem sonhava... era ele! Outro momento que me parece ainda mais belo nos Quadros de Serra vem representado pelo seguinte poema sem título: 
Aqui estou, eu te obedeço,

Faço tudo o que ordenares

Contigo rejuvenesço

Pois desterras meus pesares!

Fechei o livro que lia

No capítulo começado,

Bastou ouvir a harmonia

Do teu infantil chamado!

Deixo a leitura sem pena,

Que queres de mim, responde?

O que desejas? ordena...

Mandas queu siga-te? Aonde?

À sombra dos arvoredos

Tu vais brincar no terreiro

E queres nos teus brinquedos

Que eu te seja companheiro.

Aqui estou, vamos, descansa,

Afoito teus passos sigo,

E como tu és criança

Serei criança contigo.... ${ }^{23}$

O poema singelo se fundamenta numa interlocução cujo(a) destinatário(a) se desconhece (provavelmente a amada, mas não poderia ser, como ocorre no poema seguinte, um desdobramento do eu?). Sabemos apenas que é tratado(a) como uma figura infantil (idade tão cara ao imaginário romântico e particularmente à nossa segunda geração), seja pela fase da vida em que se encontra, seja pelo comportamento que adota. $\mathrm{O}$ eu lírico, por sua vez, indaga e, ao mesmo tempo, se submete prontamente às ordens e vontades de tal interlocutor(a). E se assim o faz é porque se sente rejuvenescer e se livrar de seus tormentos, chegando mesmo, ao fim, a se tornar criança como esse(a) outro(a). A entrega absoluta às vontades deste(a) é experimentada, paradoxalmente, como liber- 
tadora para o eu lírico e faz com que ele abandone, sem pesar, a leitura mal iniciada de um livro, representando, desse modo, a precedência conferida à vivência em detrimento do trabalho intelectual, reflexivo. A idade da inocência fala mais alto que a da razão. É assim também que, no último poema selecionado aqui, o eu tipicamente romântico, agora em diálogo aberto consigo mesmo, e, portanto, cindido em dois, investe contra a severidade, altivez e frieza da voz encarnada pela razão, em favor ou defesa incondicional do sentimento ou das razões do coração...

\section{Comigo mesmo...}

É severa demais, eu não escuto Essa voz que me fala altiva e fria, Falta nela o carinho que consola Nela falta o encanto da harmonia...

Devo ouvi-la? Por quê? Acaso o homem Há de vítima ser de um preconceito Que ele próprio criou, que nada exprime, Calcando o coração dentro do peito?

A razão! Mas quem foi que a fez tão fera, E refratária, e surda ao sentimento? Com que paga as contínuas exigências Ela, que assim nos mata a fogo lento?

Faz-nos escravos seus, c'roa de espinhos Nos reserva... Qu'estólida vaidade, Preferir prêmio tal aos sonhos nossos, As doçuras da eterna felicidade!

Não escuto a razão! O seu auxílio Chega tarde... Deixou-me ao desabrigo Quando o peito buscava o qu'ora encontro. Exulta, coração, eu vou contigo! ${ }^{24}$ 
Mas não foram esses poemas, concebidos dentro dos padrões da lírica romântica então em voga, que permitiram a Serra alcançar algum reconhecimento como poeta. Ele foi mais lembrado pelo gênero de poesia ruralista ou sertanista que surgiu no quadro da segunda geração, com Juvenal Galeno, Bittencourt Sampaio, Bruno Seabra e Fagundes Varela, entre outros. Seus poemas no gênero foram recolhidos no mesmo volume, Quadros, título que na sua singeleza se ajusta bem ao caráter meio pictural das descrições versificadas de paisagens locais. Trata-se de outra tendência menos celebrada (em relação ao indianismo, por exemplo) de nacionalismo literário, que seria como o equivalente em versos ao regionalismo ficcional, nascendo no bojo do movimento romântico. No discurso de posse da cadeira $21 \mathrm{da}$ ABL, cujo patrono era justamente o poeta maranhense, escolhido por José do Patrocínio quando a ocupou pela primeira vez, o sucessor, Olegário Mariano, evocou a lembrança de alguns versos ruralistas do poeta maranhense que chegaram a conhecer certa nomeada, a ponto de serem incluídos na Selecta clássica, de João Batista Regueira Costa. Mariano, que estudou com essa antologia, diz a respeito:

Aprendi-o insensivelmente, como aprendemos certas canções populares à força de ouvi-las repetidas a todo instante. Era a famosa "Missa do galo", correntia composição setissilábica, de feição descritiva, que, lida, ficaria depois a cantar-me no ouvido [...].

Fausto Cunha fez uma breve apreciação desse gênero de poesia em mais de um momento e, num dos ensaios, chama a atenção para a curiosa coincidência entre o poema "Rasto de sangue" de Serra e "Le jaguar" de Leconte de Lisle (único que representa o poeta francês na seleta de Marcou, Recueil de morceaux choisis, adotada em colégios brasileiros e franceses), ao descreverem, ambos, a corrida alucinante e a luta agônica de um touro atacado por jaguar, flagradas da perspectiva do atacante, "heroicizado", por assim dizer, nos dois poemas, que só se diferenciam no desfecho. Enquanto no maranhense "os dois animais rolam exangues no abismo (posição romântica, com a morte sempre a funcionar como desenlace)", no parnasiano francês, "neutro na descrição", como "um naturalista de câmara em punho", a "disparada não se interrompe, o poeta semeia dentro da paisagem o seu grupo estatuesco [...]. Só se quisermos dar de Le jaguar os alexandrinos de Le rêve du jaguar é que veremos a fera dilacerando a carne taurina". ${ }^{25}$ 
Fausto Cunha discute a hipótese de "imitação", advertindo de antemão que

[...] no romantismo brasileiro, a imitação de autores estrangeiros era não só difundida como altamente apreciada; constituía quase um gênero à parte. É claro que, escrevendo para os de seu tempo, que via de regra conheciam o original imitado, os poetas nem sempre o indicavam. Joaquim Serra nunca primou pela originalidade de suas composições. ${ }^{26}$

Nos volumes de versos, sempre nos termos de Cunha, há várias composições que são traduções indicadas como tal; outras informando que se trata de "imitação" e qual a procedência; e outras ainda, entre as supostamente "originais", que foram "imitadas" a poetas europeus, mas sem alguma referência dessa ordem, sem que isso leve o crítico, entretanto, a supor má-fé por parte do poeta maranhense com relação à autoria. Sabemos que essa questão da autoria, do original e da emulação seria posta, hoje, em outros termos muito distintos desses de Cunha, mas eu não teria como abordá-la aqui. Seguindo na sua argumentação, ele observa que, muito embora pertença a um movimento posterior, o poema de Lisle já havia sido publicado em volume de 1862 . Serra poderia ter lido o poema, embora não exista nenhuma referência ao poeta francês em sua obra.

Contrariando a hipótese de Romero, de que haveria "muita cor local" nesse poema, em que Serra retrataria "uma cena do viver das fazendas de criação do Norte" 27 , Cunha desmonta por completo a pretensão verista e nacionalista atribuída (ou projetada) pelo crítico sergipano no poema, ao atestar que a cena descrita pelo poeta maranhense é tão inverossímil quanto a do parnasiano francês:

[...] um detalhe que não passa despercebido é que tanto a composição de Leconte de Lisle como a de Serra descrevem a luta de um jaguar com um touro. Ora, até onde pude averiguar, o jaguar brasileiro ou sul-americano foi dado a conhecer na Europa em princípios do século [XIX] por diversos naturalistas que destacavam justamente esta particularidade: a de ele raramente atacar o touro, e mesmo de o temer. O antologista Marcou adverte seus alunos, através de Buffon, de que Jaguar ou Jaguara é o nome de "cet animal au Brésil, que nous avons adopté pour le distinguer du tigre". Esclarece ainda que a arte de Leconte de Lisle "accroupit le jaguar aux aguets dans les pampas de la Plata". [...] Outra informação dos naturalistas era que o jaguar habitava as savanas do Uruguai e do Paraguai. Essa confusão

26 Idem, p. 132.

27 ROMERO, S. Apud CUNHA, F. op. cit., p. 131. 
fisiográfica explica, no poema lecontiano, o fato de um jaguar brasileiro pular de um acaju brasileiro sobre um touro platino, desenvolvendo-se a disparada em meio de dunas, rochedos, pântanos, matagais [...]. Geograficamente, essa paisagem é improvável conquanto possa existir em algum lugar (Leconte era ou desejava ser de um rigor meticuloso em suas descrições). Mas também Joaquim Serra, para quem era "uma inesgotável fonte de inspiração [...] a pintura dessas paisagens esplêndidas do interior do Brasil" (o próprio, no apêndice dos Quadros), apresenta uma cena de duvidosa realidade, a que expressões como "riacho quérulo" e "cantor [da] mata" emprestam um ar de puro arcadismo. [...] é muito perigoso falar em "cor local" em certas áreas da criação. A descrição de uma cena que a Sílvio Romero pareceu típica, pelos ingredientes indubitavelmente brasileiros, pode não passar de imitação de texto alheio. O caráter nacionalista da inspiração de um poeta é um aspecto positivo; mas não devemos ficar surpresos se descobrirmos que se trata de um nacionalismo de torna-viagem, nem ser tão ingênuos a ponto de aceitarmos como autenticamente nosso o que nos impingem como tal. [...] Joaquim Serra viu a luta do touro e da onça como um simples episódio "sertanejo", um ato campestre que ele - como juiz - encerrou, lançando os dois animais num abismo. Sílvio Romero, homem pugnaz e inteligente, limitou-se a registrar o interesse paisagístico de "Rasto de sangue". Um e outro não vão além do óbvio. No entanto, mais do que ninguém, o discípulo de Tobias Barreto achava-se em condições de extrair uma "lição" desse episódio, ele que já o fizera em tantos outros casos. Como admitir que a poesia de um povo deva ser interpretada na sua literalidade lírica sem nenhuma abertura e a de outro no seu profundo contexto filosófico?

A derrota francesa na guerra com a Prússia em 1871 dera à poesia pessimista de Leconte de Lisle uma nova dimensão. [...] Leconte de Lisle estava informado de que o jaguar raramente atacava o touro. Escolheu uma situação-limite, em que, por cima da tradição e do medo, se faz mister um confronto de forças para que se opere a inexorável seleção. No espaço natural não há lugar para a coexistência pacífica, quando um tem fome e o outro é o alimento...

E Joaquim Serra? Supondo que se tivesse inspirado em Leconte de Lisle, teria ele percebido as implicações filosóficas do poema? Quase certamente que não, embora essas implicações estivessem no ar na própria época. A Europa vivia um século de instabilidade política, em que os canhões falavam mais alto. Mas no Brasil também tínhamos tido várias insurreições populares e até uma guerra, a do Paraguai - verdadeiro touro do Prata acuado por três jaguares. ${ }^{28}$

28 Idem, p. 134-7. 
Assim, pondo em xeque a dimensão localista ou verista do poema destacada por Romero, Cunha segue com a análise comparativa por outras sendas, ao evidenciar a dimensão alegórica do poema de Lisle, cujo pessimismo em relação à realidade política contemporânea vem embasado pelas teorias evolucionistas em voga, transpostas para a vida histórico-social. Como se vê acima, Cunha nega a possibilidade de um sentido dessa ordem subjacente a "Rasto de sangue", muito embora chegue a aventar uma hipótese equivalente, ao se referir à Guerra do Paraguai e às insurreições populares locais. E o nega porque, apesar do veio político-social de Serra, uma sobredeterminação de sentido dessa ordem seria impensável num contexto literário como o brasileiro, já que ela demanda um público preparado para depreender essa dimensão implícita, concebida sem alardes. Mesmo quando movido por uma preocupação social, o escritor brasileiro, dado o despreparo do público a que se dirige, tem de exprimi-la ostensivamente, "através de brados ao estilo de 'Deus, oh Deus' ou de alocuções a um povo hipotético". ${ }^{29}$ Trata-se de uma explicação um tanto mecânica e simplista, que parece fazer vista grossa ao fato de que esse mesmo contexto literário precário não impediu o florescimento de uma escrita tão politicamente sobredeterminada quanto a do amigo de Serra - e, antes mesmo de Machado, a de Gonçalves Dias ou Alencar, entre outros românticos. Apesar disso, Cunha termina o ensaio deixando em aberto as questões:

Mas de que forma, dentro da tradição crítica brasileira, se pode extrair uma filosofia, ou uma ideologia, de seu "Rasto de sangue", mero descritivo local? Teria validade, como no caso de Leconte, um estudo desse tipo? Não é estranho que exatamente o mesmo episódio sirva para desesperar um Ephraim Mikhael [que aventou a hipótese de alegoria política na poesia de Lisle] e para definir um inócuo impressionismo campestre?30

Outros críticos e historiadores dos séculos XIX e Xx praticamente desconsideraram a produção poética (ou mesmo em prosa) de Serra, de José Veríssimo a Antonio Candido. De todos os principais historiadores, aquele que veio a dar maior destaque à obra do maranhense e do gênero poético que mais o projetou, firmando doutrina sobre o "sertanejismo", foi mesmo Sílvio Romero. Diz ele que "Serra integra a plêiade maranhense que, afora os grandes nomes (Sotero dos Reis, Lisboa, Gonçalves Dias), é ainda composta por um sem-número de poetas que, como ele, produziram entre

29 Idem, p. 137.

30 Idem, p. 138.

406 • CAMILO, Vagner. Entre "o Romantismo tão gasto e o Realismo tão vasto" 
os anos de 1850 e $1870 "{ }^{31}$ Esse sem-número pode, na verdade, ser mais específico quantitativamente: são os 52 poetas que integram o Parnaso Maranhense, dos quais se destacam seis ou oito e, dentre eles, Serra que, tendo vivido e gozado "da bela camaradagem de peregrinos talentos, fez parte daquele grupo que escreveu em colaboração o interessante romance $A$ casca da caneleira" ${ }^{32}$ Em estreita associação com o temperamento do poeta, o historiador naturalista destaca, na poesia do maranhense, a "simplicidade das cores", o "brasileirismo dos quadros. Sente-se imediatamente que se está a tratar com um homem que veio do povo, que conviveu com ele, que o conhece, que se inspirou de sua poesia, de suas lendas, de suas tradições". ${ }^{33}$ Isso Serra jamais abandonaria, mesmo depois do convívio que viria a ter mais tarde com os autores estrangeiros que estudou e traduziu. Romero adverte para os riscos de um gênero popular como esse que não precisa ser cultivado apenas por populares, mas munidos de gênio capaz de tomar "o motivo popular, a lenda, o conto, a tradição, o costume", e extrair "de tudo isto a seiva poética e d[ar]-lhe a forma artística geral, universal. Entre nós Joaquim Serra é dos melhores cultivadores do gênero; creio que ele e Bittencourt Sampaio são os mais eminentes que possuímos neste sentido". ${ }^{34}$

Ao caráter natural e popular dos temas na poesia de Serra, associa-se a suposta espontaneidade da escrita de Serra (argumento que pode ser posto sempre sob suspeita quando se trata de poetas românticos), que o historiador sergipano ressalta, decerto, pelo desprezo (implícito) em relação ao artifício ou engenho:

Serra escreve correntemente, sem rabiscar, sem preocupações estilísticas. O verso lhe sai natural e espontâneo; se vem errado, não o corrige, deixa-o ficar assim mesmo. Por este modo se explicam bastantes versos incorretos em poeta tão correntio e fluente. No gênero que temos discutido o característico do escritor maranhense está em escolher sempre um fato simples e narrá-lo tal qual pelo seu lado mais genérico; faz um esboço rápido, claro, de tom realista, num desenho firme, porém elementar e sem complicações. Por isso $O$ mestre de reza, Rasto de sangue, Cantiga de viola, O roceiro de volta são modelos do gênero..$^{35}$

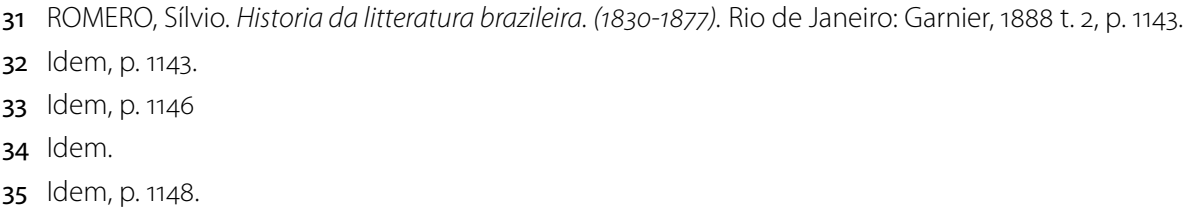


Romero lembra que "Joaquim Serra não tem tocado somente a viola de sertanejo; tem manejado também a harpa das inspirações sociais e a lira das emoções amorosas. Neste gênero são belíssimos os versos "A Minha Madona", ${ }^{36}$ outra das peças de resistência do poeta maranhense, escolhida por Bandeira para sua Antologia dos poetas da fase romântica, apesar de alguns historiadores minimizarem-lhe o mérito por julgá-la "imitação" de um poema de Pindemonte... ${ }^{37}$ Volta a insistir que, "apesar de ter bastante lido e se haver ilustrado bastante, pode-se em rigor dizer que fundamentalmente o seu espírito conserva a mesma atitude e a mesma frescura primitivas". ${ }^{38}$

De toda essa produção poética de Serra, entretanto, como já observei na introdução deste ensaio, interessam aqui não esses quadros rústicos, mas sim os tableaux urbanos que ele traçou em nove poemas ${ }^{39}$ marcados pelo intenso diálogo com o teatro, nos quais se pode perceber o traço do humor aquilatado por Machado.

A propósito desse humor, antes de passar a esses tableaux, é importante lembrar com Karlheinz Stierle, quando historia os antecedentes do gênero consagrado por Baudelaire, que, no caso da poesia lírica, Victor Hugo foi

[...] o primeiro a ter erigido Paris como lugar de uma experiência mítica enquanto experiência do sublime, e ter dado assim à experiência da cidade uma dimensão nova. Desde Horácio e Juvenal, a pintura da grande cidade era essencialmente ligada à sátira, no sistema europeu dos gêneros do discurso poético que se formou lentamente. A pintura poética da cidade era essencialmente uma sátira da cidade, que buscava fazer tomar consciência não tanto da totalidade da cidade, mas de aspectos isolados dos quais era frequentemente acentuado o lado negativo. O colapso, no discurso romântico, do sistema dos gêneros definidos pelos paradigmas oriundos da Antiguidade - colapso que abriria a possibilidade de fazer advir à linguagem, nos novos gêneros poéticos híbridos,

36 Idem, p. 1156.

37 É o que ocorre, por exemplo, com Massaud Moisés quando afirma que "a originalidade do poeta maranhense entrou a sofrer abalo desde o instante em que se demonstrou [...] que as suas peças de resistência,'A Minha Madona' e 'Rastro de Sangue', devem inspiração respectivamente ao italiano Pindemonte e ao francês Leconte de Lisle". Já observei de passagem, a propósito de Cunha, o quão problemático é esse tipo de avaliação sobre a "imitação", originalidade, emulação etc. entre os românticos. Ver MOISÉS, Massaud. História da literatura brasileira. Das origens ao romantismo. São Paulo: Cultrix, 2001, t. 1, p. 549.

38 ROMERO, Sílvio. Op. cit., p. 1161. Ver ainda as considerações de Romero no Compêndio de história da literatura brasileira (Rio de Janeiro: Livraria Francisco Alves, 1906), escrito a quatro mãos com João Ribeiro.

39 Veja os poemas reproduzidos adiante, a partir da página 546. 
novas dimensões da experiência histórica - criava também, portanto, as premissas que permitiam uma apropriação inédita da cidade pela poesia. ${ }^{40}$

Em descompasso com Hugo e demais românticos que representaram essa experiência da cidade em um novo discurso que rompia com esse sistema dos gêneros referido por Stierle, Serra persiste na pintura citadina em registro próximo ao satírico - embora o nomeie como "humorístico", conceito moderno, que os românticos tornaram muito mais matizado do que a forma tradicional do riso da sátira. ${ }^{41} \mathrm{E}$ será nesse registro já anacrônico para a época que ele tratará de algumas das experiências mais características da cidade moderna examinadas pelo mesmo Stierle nos tableaux de Paris, como a flânerie, o trem de ferro e demais transportes urbanos (e o tipo de convívio social que eles instauraram), os encontros fortuitos, o fluxo de passantes, certo cosmopolitismo encarnado pela presença e pela moda estrangeiras (francamente repudiado pelo zelo do provinciano que as vê como forma de corrupção dos autênticos valores); a prostituição, a associação com o modelo arquetípico de cidade representado por Babilônia...

Stierle examina ainda as contribuições vindas das artes plásticas para os tableaux collectifs nos periódicos ilustrados, em especial as litografias excepcionais de Honoré Daumier, cujas cenas da comédia urbana de Paris muito inspiraram o Porto-Alegre de A Lanterna Mágica, que recriou, entre outros aspectos, os episódios de rua, os tipos característicos e os petits métiers concebidos pelo grande caricaturista e ilustrador francês, ${ }^{42}$ mas ambientando-os num Rio de Janeiro anterior aos melhoramentos introduzidos na cidade pelo Barão de Mauá, aos quais remeterão os poemas humorísticos de Serra. No entanto, é possível que o poeta maranhense - admirador de Porto-Alegre, como registra uma das notas a Fábio - tenha colhido alguma sugestão no humor e na vivacidade crítica das cenas urbanas de A Lanterna Mágica para atualizá-las no Rio da era Mauá.

O caráter moralizador da sátira parece bem se ajustar aqui à perspectiva do campônio esposada pela persona de Serra que, reconhecendo na província a sede dos autênti-

40 STIERLE, Karlheinz. La capitale des signes. Paris et son discours. Trad. Marianne Rocher-Jacquin. Paris: Éditions de la Maison des Sciences de L'Homme, 2001, p. 363-4.

41 Ver, entre outros, VEGA, C. F. de la. El secreto del humor. Buenos Aires: Editorial Nova, s.d, p. 117 ss.

42 Para o diálogo entre Daumier e Porto-Alegre, ver, neste volume, algumas das ilustrações de A Lanterna Mágica, bem como o ensaio de ANGOTTI-SALGUEIRO, Heliana. A comédia urbana: de Robert Macaire à Lanterna Mágica. Representações e práticas comparáveis na imprensa ilustrada no século XIX - entre o romantismo e o realismo, p. 174-191. 
cos valores não contaminados pela importação de modas e costumes corruptíveis, concebe a cidade ${ }^{43}$ como "diabólica emboscada". Essa concepção se evidencia desde o primeiro poema da seção, que trata da atração despertada no eu poético por uma bela inglesinha (uma passante, mas com endereço certo, fácil de reencontrar dentro do contexto urbano mais tacanho da cidade carioca) que cruza seu caminho na companhia dos pais, levando-o a segui-la, desesperado, pelas ruas da cidade até reencontrá-la numa igreja protestante, faltando, assim, com a promessa de fidelidade feita à sua amada. A culminância desse processo de sedução, que pode levar um homem à perdição na cidade "moderna", é representada pelas "falsas virgens" de outro poema, pelas ninfas alcazarinas e, no limite extremo, pelas camélias das devesas do Jardim Botânico, que vêm usurpar o espaço outrora reservado ao bemcomportado namoro burguês.

Mais anacrônico se mostra esse registro satírico quando se observa que ele é empregado por Serra em versos que visam a encenar um momento de crise do próprio romantismo com o despontar das propostas realistas, conforme veremos mais à frente. Assim, sem chegar a incorporar a dicção inaugurada pelo romantismo na representação da experiência da cidade, que se modernizava mais lentamente aqui, o "ecletismo" (título de um dos poemas) dos Versos de Pietro de Castellamare aponta para a crise desse mesmo movimento romântico no momento inaugural do realismo como escola, sobretudo no teatro, mas também com as polêmicas instauradas pela Questão Coimbrã.

\section{A cena urbana na poesia humorística de Joaquim Serra, vulgo Pietro de Castellamare}

Publicado em 1868, sob o título versos de Pietro de Castellamare - um dos vários pseudônimos que adotou na imprensa (Amigo Ausente, Ignotus, Max Sedlitz, Tragaldabas...) -, o livro de Poemas de Joaquim Serra, dado à estampa em S. Luís do Maranhão (Imp. B. de Mattos), é dividido em três partes: a primeira, composta de traduções; a segunda, de poemas originais, e a terceira, de humorísticos. É esta última que interessa aqui.

Para as relações críticas do poeta satírico com a cidade, ver HODGART, Matthew. La sátira. Trad. Angel Guillén. Madrid: Ediciones Guadarrama, 1969, p.135 ss. Ver também KERNAN, Alvin B. The cankered muse: satire of the English Renaissance. New Haven: Yale University Press, 1959.

410 • CAMILO, Vagner. Entre "o Romantismo tão gasto e o Realismo tão vasto" 
Gostaria, primeiramente, de tecer algumas considerações sobre a data e o local de publicação dos Versos de Pietro de Castellamare, que saiu no ano da transferência definitiva do poeta para a Corte, embora a maioria dos poemas date de 1866 , portanto de uma época em que ele ainda residia em São Luís. No entanto, eles reportam ao Rio de Janeiro, o que se explica pelo fato de Serra ter visitado a Corte justamente em 1866, na qualidade de representante de sua província para a Exposição Nacional daquele ano - a segunda no gênero entre nós, inspirada pelas exposições universais e para as quais as daqui eram uma espécie de preparação, logo reproduzidas também em escala regional. Esse circuito das exposições marca o ingresso do Brasil na era do espetáculo, inscrevendo-se plenamente "na ótica da moderna exhibitio burguesa". ${ }^{44}$ Na exposição de 1866, o Maranhão se fez representar, entre outras coisas, pela amostra da qualidade alcançada por sua indústria tipográfica, que tornou São Luís um importante centro impressor no século XIX, servindo aos autores da região Norte-Nordeste, graças não só aos baixos custos, mas sobretudo ao alto padrão dos serviços prestados por seus dois melhores artesãos: José Maria Corrêa de Frias (autor da Memória sobre a tipografia maranhense, escrita especialmente para a Exposição Provincial de seu estado, realizada no mesmo ano) e Belarmino de Mattos. Este último, conhecido como o Didot maranhense, numa alusão à famosa dinastia de tipógrafos franceses, e considerado por José Veríssimo como o melhor impressor que o Brasil já teve, foi o mais destacado participante da Exposição de 1867. Em sua tipografia seriam impressos os Versos de Serra, ao lado de outras tantas obras de autores que integram o Pantheon Maranhense, de Henriques Leal.

A menção à Exposição Nacional de 1866 não é mero dado circunstancial, mas referência contida nos próprios Versos e logo no primeiro poema da seção humorística. A persona poética (construída com alguns traços marcadamente biográficos), depois de cumpridas as obrigações junto ao Júri da Exposição que a trouxe ao Rio, se deixa levar pelo movimento da cidade, seus atrativos, armadilhas e seduções, embora viesse "resolvido/ a apressar a romagem/ e não ser acometido,/ ou de amor sério ou ligeiro,/ neste Rio de Janeiro". Como vimos, faltando com a palavra dada (provavelmente) à amada, deixa-se seduzir pela tal inglesinha, em busca da qual sai pelas ruas da cidade. E ao fazê-lo, vai revelando ou mapeando esse espaço urbano desde a saída da Exposição Nacional e integrando-o aos Versos não só como pano de fundo, mas diria mesmo como personagem. 
Foi justamente isso o que me despertou interesse quando li pela primeira vez esse conjunto de apenas nove poemas: além do registro humorístico, a notação histórica e o modo pelo qual Serra traz a cena urbana ao domínio da poesia, o que representava, então, um procedimento pouco comum no gênero, para não dizer sem precedentes entre nós. ${ }^{45}$ Sem dúvida, o tema, as cenas e os tipos urbanos evocados, bem como a dicção e o registro empregados, não eram novidade nos outros gêneros, como o romance, a crônica e o teatro, mas, no caso da poesia, essa ordem de assunto não parecia nada comum. Basta lembrar que, logo após a publicação de Quadros, Varela propunha abordar seriamente o tema em seus Cantos do ermo e da cidade (1869). O que vemos, todavia, nesses cantos não vai muito além de lugares-comuns repisados pela velha oposição entre campo e cidade, tratada em termos convencionais e abstratizantes, fazendo, pelo menos da cena urbana, algo completamente despaisado. ${ }^{46}$ Nesse sentido, em termos de tradição local, Serra parece gozar de certa precedência, mesmo que ainda preso a um registro satírico tradicional, conforme vimos atrás.

Ainda depois dele, a composição do cenário urbano demoraria a marcar presença na poesia brasileira, seja em que registro for. Alguns críticos se ocuparam de investigar os prenúncios das figurações urbanas antes de seu advento na lírica modernista e creio que, descontadas as deambulações do Eu de Augusto dos Anjos em "As cismas do destino", eles chegaram a retroceder no máximo até a flânerie do gaúcho Marcelo Gama pelas ruas da cidade, que constitui, ele próprio, uma exceção em relação à vertente simbolista dominante entre nós.

Mas Serra também já flanava "Ao acaso" (título de um dos poemas), algumas décadas antes, pelas ruas do mesmo Rio quando este, ainda sob regime imperial, começava a ser dotado de certos benefícios modernos com a liberação (devido à proibição do tráfico negreiro) dos capitais antes investidos em mão de obra escrava. É significativo que a abordagem desse temário se dê em um momento em que a Corte conheceu algum progresso em termos de urbanismo e cosmopolitismo. Nada radicalmente transformador, pois isso só viria a ocorrer, como sabemos, na virada do século xx com Pereira Passos - e sempre muito aquém das grandes intervenções urbanísticas europeias que o inspiraram, como a hausmanniana, coetânea dos tableaux baudelairianos.

Salvo, talvez, uma ou outra evocação dos espaços urbanos, como na trajetória do Catumbi ao Catete descrita pelo eu azevediano da segunda parte da Lira dos vinte anos. Ou ainda, sempre em dicção humorística (quando não obscena), nos censurados poemas livres do baiano Laurindo Rabelo.

46 A título de ilustração, veja-se um poema como "Em viagem". VARELA, Luís N. Fagundes. Cantos e fantasias e outros cantos. São Paulo: Martins Fontes, 2003, p. 256. 
O fato é que nos anos 1850-60 o Rio assistiu à instalação da iluminação a gás, ao calçamento das ruas, à modernização dos transportes, aos vapores singrando as águas, ao trem de ferro e ao Passeio Público, entre outras benfeitorias. Estamos, em suma, em plena era Mauá, quando a velha cidade colonial começa a ganhar as primeiras marcas do progresso, impressas, em sua maioria, pelo barão, como resume seu principal biógrafo:

A verdadeira fonte de sua reputação de pioneiro vinha dos empreendimentos já montados no Rio de Janeiro, a capital do país e de seu império. A cidade de quase 300 mil habitantes havia mudado muito nos últimos anos. O vilarejo colonial transformara-se em metrópole, e todos os signos dessa transformação tinham a marca do barão. Os navios a vela davam lugar aos vapores - fabricados por Mauá nos estaleiros e nas oficinas da Companhia Ponta de Areia. Os trilhos da Estrada de Ferro de Petrópolis substituíam as estradas poeirentas e os vagões, as tropas de mulas. A vida noturna era outra desde que a Companhia de Iluminação a Gás do Rio de Janeiro, que ele comandava, trocara os velhos candelabros de óleo de peixe pela farta luminosidade dos lampiões. Mesmo as velas que os pobres consumiam não se fabricavam mais em casa, mas na Companhia de Luz Esteárica, da qual era acionista. A água para os habitantes não vinha mais dos aquedutos de pedra, mas dos canos de ferro instalados por seus engenheiros. O mangue que cercava a cidade, impedindo sua expansão, começava a desaparecer: Mauá tinha ganhado a concorrência para fazer a primeiro grande obra de drenagem da cidade. No porto outra novidade moderna: dominando a paisagem, um grande dique flutuante de ferro que o barão mandara construir. ${ }^{47}$

Tais mudanças vieram a afetar de modo substancial a vida na Corte, a sociabilidade e os costumes. A iluminação a gás fez prolongar a vida social em ruas e parques da cidade, e locais como o Passeio Público passaram a ser um lugar de se ver e ser visto. As mulheres começavam a ganhar um pouco de liberdade em relação à severa vigilância e disciplina patriarcais, rompendo o claustro do universo doméstico em direção às ruas. ${ }^{48}$ Como nota Luís Felipe de Alencastro:

O início da iluminação a gás na parte central da cidade atrai para fora das casas - para os cafés, as confeitarias e os restaurantes - as famílias que antes só se expunham ao olhar

47 CALDEIRA, Jorge. Mauá: empresário do Império. São Paulo: Companhia das Letras, 1995, p. 27-30.

48 Cf. VIOTTI DA COSTA, Emília. Urbanização no Brasil no século XIX. Da Monarquia à República (Momentos decisivos). São Paulo: Editora da UNESP, 1999.

Teresa revista de Literatura Brasileira [12|13]; São Paulo, p. 384-420, 2013 • 413 
público nas missas dominicais e, às vezes, nos teatros. [...] Nos anos de 1860 a iluminação a gás entra nas casas mais ricas e, em 1874, cerca de dez mil casas já dispunham desse conforto. No ambiente iluminado das casas, dos salões e dos cafés, a aparência individual devia revestir-se de novos atributos estéticos. Chapéus, luvas e vestidos, muitas vezes provenientes de estoques que as crises econômicas ou as viradas da moda haviam tornado invendáveis na Europa e nos Estados Unidos, são importados no Rio de Janeiro. Alguns desses adereços deixam entrever os hábitos e as expectativas íntimas das camadas ascendentes da sociedade imperial. ${ }^{49}$

Essas transformações urbanísticas do período deixaram suas marcas nos poemas de Serra, ao longo do itinerário traçado por sua persona humorística que, partindo do Campo de Santana (onde foi montada a Exposição de 1866, na Casa da Moeda), segue pela rua Uruguaiana, rua dos Ciganos, o largo do Rocio (onde havia pouco fora instalado o primeiro monumento cívico: a polêmica estátua equestre do Imperador, ironizada em mais de um poema)... Esse perímetro central modernizado é a região onde tal persona efetivamente transita nos versos, embora os poemas ainda evoquem, de passagem, Santa Teresa, Tijuca e Andaraí, de onde retorna no trem de ferro (outro marco significativo da modernidade à época). Há, ainda, um poema que, afastando-se da região central, detém-se no Jardim Botânico, transfigurado em versão degradada do jardim edênico ou do hortus conclusus, como espaço de queda moral e depravação por causa das camélias que "povoam devesas", expulsando as burguesinhas e seus castos idílios amorosos, para fazer do jardim público o "feudo de algumas publicanas...."E vale lembrar aqui que foi justamente em fins dos anos 1860 que o Jardim Botânico sofreu mudança significativa de sua destinação científica original, quando da criação em 1808 com a vinda da família real, embora acabando por ser mais para desfrute privativo de d. João vi. Além dessa destinação, e de ser também "cenário idílico para as mentes pautadas pelos valores iluministas", espaço propício para se desenvolver "a arte de passear", como demonstrou Hugo Segawa, o Jardim Botânico, cada vez mais franqueado como área de recreação durante o Primeiro e o Segundo Reinados, teve alguns de seus recantos transformados em reduto de prostituição, justamente nesse período do poema. É o que registra João Barbosa Rodrigues, que fala, analogicamente, de Mênades em fúria e ruidosos rituais báquicos nas moitinhas próximas do lago:

49 Cf. Vida Privada e Ordem Privada no Império. In ALENCASTRO, Luiz Felipe de; NOVAIS, Fernando (Dir.). História da vida privada no Brasil 2. Império: a Corte e a modernidade nacional. São Paulo: Companhia das Letras, 1997, p. 84-5.

414 • CAMILO, Vagner. Entre “o Romantismo tão gasto e o Realismo tão vasto" 
[...] foi aberto francamente ao público e houve mesmo a condescendência de colocarem-se aí muitas mesas de madeira, como nas estalagens de aldeia. [...] Foram então facilitados os piqueniques ao ar livre e tornou-se um simples jardim de recreio [...] [e que] [...] com a força de vegetação no clima do Rio de Janeiro o passeio tornou-se em pouco tempo um grande parque encantador, excitando a admiração dos visitantes. Infelizmente, como triste reverso da medalha, certas alamedas sombreadas, certos grupos lembravam, ao menos pela elegância e beleza grega, os bosques sagrados de Paphos e Amathonte, enquanto, nas moitas próximas do lago, ruidosos cânticos de culto do Baccho moderno recordavam os furores harmoniosos das Menades. ${ }^{50}$

Mas é naturalmente nos poemas que remetem à região central do Rio que as marcas da modernização vão se deixar entrever através dos itinerários da persona humorística, que alterna a caminhada pelo passeio agora bem calçado ou pela rua bem asseada - onde ocorre por vezes ser levado pela movimentação dos passantes - com o deslocamento nos novos e velhos meios de transporte à disposição: caleças, coupés, tílburis, maxambombas e o "wagon de Ave-Maria" que traz o eu de volta do Andaraí, reclamando, todavia, da "macieza/ que tem o ferro-carril" e preferindo, antes, "toda a aspereza/ de um mac-adam tosco e vil".

Como se pode notar, a perspectiva de Serra não é nada favorável ao progresso e à modernização urbanística de que sua poesia dá notícia. Isso se torna ainda mais evidente quando o poeta se volta para as reverberações dessa modernização no plano da vida social e cultural: os novos hábitos, os comportamentos mais cosmopolitas, a relação com a presença estrangeira na cidade, a imitação ou a incorporação dos padrões ou modelos europeus, em particular o afrancesamento da cultura e do estilo de vida, visível inclusive no plano da língua, ironizado pelos estrangeirismos que despontam em vários versos...

Exemplo significativo disso está nos versos dedicados ao Alcazar lírico. Serra partilha com o Macedo das Memórias da rua do Ouvidor e o Machado das crônicas do Dr. Semana, entre outros, a visada negativa diante do impacto (em vários níveis) decorrente da instalação desse café-concerto no Brasil, com o qual o Rio passou a ter atrativos noturnos típicos da vida de grande cidade. Instalado em 1859 por M. Arnaud, o Alcazar não foi o primeiro café-concerto da cidade, mas o que inaugu-

50 RODRIGUES, J. B. Hortus Fluminensis ou breve notícia sobre as plantas cultivadas no Jardim Botânico do Rio de Janeiro, apud Hugo Segawa, Os Jardins botânicos e a arte de passear. Ciência e Cultura, vol. 62, n. 1. São Paulo, 2010, p. 52. 
rou um novo tipo de espetáculo, baseado no vaudeville, na mágica ou féerie, em "números de canto, operetas, representações de ginástica e bailados interpretados por um belo elenco de atrizes francesas, que levantavam suas pernas, vestidas com justíssimas calças de seda, ao ritmo do cancã, fazendo as delícias do público majoritariamente masculino que frequentava aquela casa e assistia às récitas fumando e bebendo cerveja". ${ }^{11}$ Eram frequentes os escândalos e as brigas por causa da troupe de francesinhas levando à perdição homens casados e jovens solteiros, que dissiparam a fortuna familiar em troca dos favores das novas musas ou ninfas, dentre as quais ficou muito famosa Mlle. Aimée. Com humor, diz Décio de Almeida Prado que, quando ela deixou o país, depois de quatro anos de atuação no Alcazar, segundo as más-línguas, "as esposas e mães de família soltaram rojões, comemorando a volta ao lar dos maridos e filhos"... ${ }^{2}$

Mas além das questões morais, a crítica negativa ao Alcazar caminhava também no sentido do "abastardamento" da cena nacional e da transformação do teatro em puro entretenimento, abandonando suas preocupações literárias e edificantes, e minando o trabalho realizado pelos autores ligados ao Ginásio Dramático, que contribuíram, de modo muito estimulante, para o florescimento de uma dramaturgia brasileira escrita em moldes realistas. Nos Versos de Serra, o Alcazar é tematizado em mais de um momento e criticado nesses dois sentidos. É esse, por exemplo, o teor do poema justamente intitulado "O Alcazar", no qual emprega o louvor para denegrir. Recorre ardilosamente à tópica da falsa modéstia, ao se identificar como um campônio lá do norte (que é, no fim das contas, a perspectiva deslocada da qual investe criticamente em todos os poemas), cuja visão simplória de filho do mato, de rude montanhês, entretanto, é flagrantemente desmentida pelo manejo tortuoso do recurso requintado da ironia, com a qual desanca o morador cosmopolita e moderno, frequentador assíduo do café-concerto, embora aparentemente fazendo o encômio dos modismos franceses encarnados no teatro alcazarino. E por meio das metáforas condimentares, mostra como a apimentada arte alcazarina, com sua malícia ou licenciosidade, caiu no gosto popular e, para desgosto da arte erudita ou clássica, "suplanta o mel do Himeto e o ático sal e tudo o que a antiga musa canta"... Reiterando a exposição do corpo, mostra como as vestimentas sumárias das ninfas alcazarinas teriam influído na moda feminina em geral, impondo um novo figurino às mulheres, que baniu de no Rio de Janeiro da segunda metade do século XIX. História e perspectivas, Uberlândia (34), jan.jun.2006. 
vez a tão execrada saia-balão, já uma vez satirizada por Bernardo Guimarães - a cuja poesia humorística a persona de Serra se pretende alinhar, elegendo, desse modo, uma vertente romântica menos canônica da obra do autor de A escrava Isaura. ${ }^{53}$

Em seu conjunto, os poemas humorísticos de Serra contribuem para redimensionar o que foi esse período de fins dos anos 186o, quando o romantismo dava visíveis sinais de esgotamento como escola, embora a terceira geração ainda estivesse alçando voo à época, nas asas do condor castroalvino. O fato é que o realismo já estava em pauta pelo menos no teatro, ainda que sem se afirmar como opção estética válida para os demais gêneros. É o que Serra busca dramatizar num dos únicos poemas, em que perde de vista a cena urbana fluminense e seu cosmopolitismo (mas não o momento histórico literário), para representar essas tensões estéticas em um registro fantástico. Trata-se de "Ecletismo", em que Serra encena o embate entre escolas através da representação de um sabá, cujo intertexto remete a um dos episódios mais celebrados do romantismo: "A noite de Valpurgis" do Fausto, como já tive oportunidade de assinalar, ao examinar outra das reescritas locais do mesmo episódio goethiano, com o pandemonismo sertanejo de "A orgia dos duendes" (então publicado na coletânea de Poesias de 1865), no qual Bernardo Guimarães genialmente mobiliza uma série de personagens do folclore ou do anedotário popular e da fauna local para encenar uma versão grotesca, perversa e sarcástica do nacionalismo romântico. ${ }^{54}$ Dada a evocação de Bernardo poeta satírico ${ }^{55} \mathrm{em}$ outro momento da poesia humorística de Serra, é possível supor que aqui também o maranhense tenha se inspirado no exemplo do mineiro, para se apropriar livremente do modelo fáustico, mas a fim de encenar matéria diversa: o referido embate entre as duas escolas literárias. O que vale dizer, o romantismo em seu estertor e o realismo em seu despontar entre nós, seja no domínio da arte dramática, seja nos ecos da Questão Coimbrã referidos dire-

Examinei detidamente os poemas satíricos de Bernardo Guimarães sobre a saia-balão e a moda feminina em CAMILO, Vagner. Risos entre pares: poesia e humor românticos. São Paulo: Edusp; Imprensa Oficial, 1997, $101 \mathrm{SS}$.

54 CAMILO, V. Walpurgisnacht e o pandemonismo sertanejo: na trilha do humour noir. Risos entre pares, op. cit., p. $159-79$.

55 Na verdade, a admiração de Serra por Bernardo Guimarães vai além da poesia satírica, fazendo-se sentir na poesia lírica e campesina do primeiro, como ele trata de admitir em seus Quadros. Salvador de Mendonça chega a destacar essa dívida para com o poeta dos Cantos da solidão no prólogo do livro. Ver SERRA, Joaquim. Quadros. Rio de Janeiro: B. L. Garnier, [1873]. 
tamente nos versos. A dimensão convulsiva ou agônica do episódio goethiano se dá aqui por associação com o bíblico Vale de Josafá, onde ocorrerá o julgamento final, de acordo com o livro de Joel. O clima de tormento e horror é ainda reiterado pela evocação de peças e dramas cujo tema envolve a ambiência terrificante da Inquisição ou os conflitos entre cristãos e mouros...

O embate entre escolas e modas teatrais traz à cena figurações fantasmáticas e grotescas de protagonistas de peças emblemáticas de diferentes escolas: não só romântica e realista, mas também clássica. Basta notar que o ritual sabático é presidido por ninguém mais, ninguém menos que Inês de Castro, provavelmente evocada por associação não apenas com a personagem histórica, mas também pela versão do mito na tragédia de Antonio Ferreira, marco do classicismo português que voltaria à cena nas tentativas arcádicas de restauração desse gênero com Reis Quitta no XVIII, cuja Castro seria refundida "por João Baptista Gomes, numa versão que, embora inferior, teve o favor do público": A nova Castro. ${ }^{56}$ Por essas célebres versões dramáticas (a par, é claro, da versão camoniana que imortalizou literariamente o mito), acredito ser possível afirmar que Inês comparece no poema como representante do teatro clássico, cercada de uma coorte de espectros de diferentes épocas e tradições que, como ela, foram destronados e literalmente expulsos de cena por uma nova moda.

Péricles Eugênio da Silva Ramos lê essa nova moda não expressamente identificada pelo poeta maranhense como referência ao realismo. Mas se assim for, como se explica o fato de que as personagens daquele que inaugura o teatro realista francês (o Armand Duval da Dama das camélias, além da menção expressa ao Demi-monde, ambas de Dumas Filho) estejam também reduzidas à condição espectral das demais, sendo igualmente expulsas da cena? Nesse sentido, a nova moda seria mesmo o Realismo ou quem sabe (até mesmo porque designada como moda) o teatro cômico e musicado representado pela opereta, mágicas e demais formas de entretenimento encenadas no Alcazar, o qual lançaria no limbo toda a dramaturgia literária, inclusive a realista? Como o poema não esclarece a nova moda, fica a dúvida, porque as duas tendências em confronto efetivamente nomeadas logo no início dos versos são mesmo o Romantismo tão gasto e o Realismo tão vasto. Mas veja que se essa definição parece encerrar uma escolha - reconhecendo no realismo uma alternativa válida pela amplitude de possibilidades novas que oferece -, a sequência dos versos demonstra o contrário, desqualificando ambas as escolas: "Se o romantismo se ador- 
na/ De farrambambas sem par,/ O realismo água-morna,/ Nenhuma poesia encerra,/ Porque anda terra-a-terra,/ Como nós, sobe ao ar!".

Note-se ainda que, se o embate parece encerrar a exclusão mútua das tendências estéticas em confronto, o título aponta para um convívio pluralista: seria a constatação de um estado de coisas ou uma proposta conciliatória de diferentes correntes artísticas e estilísticas? Pois não custa lembrar que o movimento de reação ao romantismo teatral dos anos 1850 conhecido como École du bon sens não chegara a propor uma poética teatral para "opô-la à dos românticos, como estes haviam feito em relação aos clássicos. Sob a proteção de uma regra única, a do bom-senso, permitiram-se [justamente] certo ecletismo e alguma conciliação em relação a formas teatrais". ${ }^{77}$ Estaria Serra propondo algo nesse sentido, tendo já por horizonte o romantismo constituído? Nem o poema responde explicitamente, nem algo na sua produção posterior permite responder assertivamente a isso. São questões que ficam, por enquanto, em aberto.

Mas gostaria de encerrar voltando à poesia, que é o que efetivamente me interessa. A alternativa estética diz respeito também a ela, embora a reflexão se faça a partir do teatro (talvez porque fosse o gênero em que o realismo se afirmou mais cedo). Não só "Ecletismo", mas todos os poemas do livro, como já disse, contribuem para redimensionar (ou tornar ainda mais problemático) o que foi esse período de fins dos anos 1860 e penso especificamente na discussão que aparece entre certos críticos e historiadores a respeito do (temo até em pronunciá-lo aqui!) realismo em poesia, discussão marcada por vários equívocos, imprecisões conceituais, anacronismos e relativismos - e por isso descartada pelo debate crítico-historiográfico. Lembro um desses críticos, só para indicar o problema. O já citado Silva Ramos fala de um "realismo humorístico" na poesia romântica (no qual insere Serra) que evoluiu depois para o realismo tout court:

Nasceria na segunda geração romântica o "realismo humorístico", que se viria a converter mais tarde no realismo "tout court": Álvares de Azevedo [...] fundou-o entre nós na segunda parte da Lira dos vinte anos, com um prefácio teorizador [...]. O realismo humorístico de Álvares de Azevedo frutificaria em Fagundes Varela ("Antonico e Corá", "Mimosa", "Leviandades de Cíntia”) ou em Castro Alves ("Uma Página da Escola Realista”). Já como realismo puro e simples, presente, aliás, em porções de "Ideias íntimas" de Azevedo, surgiria sobre assunto internacional no Wiesbade de Pedro Calasãs 
(1864) e viria opor-se definitivamente ao romantismo (coisa que o próprio Álvares de Azevedo já fazia, ao contrapor seu terra a terra ao sentimentalismo, que dava por esgotado por volta de 1850): combatê-lo-ia como reação. Posteriormente à questão coimbrã, seria ele uma bandeira, como se vê em versos do todavia romântico Joaquim Serra [...]. Também da nota realista que incide sobre a nudez feminina em cancãs ou alcovas já Joaquim Serra tem coisas mais fortes que Joaquim de Calasãs com seus simples pedaço de perna [...] Carvalho Júnior, Teófilo Dias, Adelino Fontoura já poderiam vir; o realismo antirromântico, porém, nascera no romantismo, movimento excepcionalmente rico de direções. ${ }^{8}$

Não retomo aqui os comentários de Fausto Cunha, mais cuidadoso no emprego do conceito de realismo romântico (contradição em termos). Mas o fato é que, por ora, apesar das associações forçadas presentes na linhagem discutível eleita por Silva Ramos, e apesar de certa incompreensão para com sua concepção do todo da poética de Álvares de Azevedo, o fato é que, no caso de Serra e destes poemas humorísticos em particular, a indagação pelo realismo (sem que isso implique afirmá-lo de modo categórico, desobrigando-se de precisá-lo conceitualmente) tem sua razão de ser, dada a sua tematização explícita em "Ecletismo" e tomando por referência o "ideal coimbrão". Daí, também, entendermos um pouco melhor o sentido da cena urbana de que se alimentam os Versos de Pietro de Castellamare.

Vagner Camilo é professor de Literatura Brasileira na Universidade de São Paulo, autor de Risos entre pares: poesia e humor românticos (Edusp/Imprensa Oficial, 1997) e Drummond: da rosa do povo à rosa das trevas (Ateliê/ANPOLL, 2000). 